\title{
EVALUATIONS OF THE APPARENT ACTIVATION ENERGY DISTRIBUTION FUNCTION FOR THE NON- ISOTHERMAL REDUCTION OF NICKEL OXIDE NANO-POWDERS
}

\author{
Bojan Ž. Janković ${ }^{a}$, Marija M. Janković ${ }^{b}$ \\ a University of Belgrade, Faculty of Physical Chemistry, \\ Department of the Dynamics and Structure of Matter, \\ Belgrade, Serbia, \\ ${ }^{b}$ University of Belgrade, Institute Vinča, Radiation and \\ Environmental Protection Department, Belgrade, Serbia
} FIELD: Materials, Chemical Technology
ARTICLE TYPE: Review Paper

DOI: 10.5937/vojtehg62-4585

\section{Summary:}

The differential conversion curves of the non-isothermal NiO reduction process by hydrogen are fitted by the Weibull (non-isothermal) probability density function (Wpdf), in a wide range of the degree of conversion $(\alpha=0.06-0.96)$. It was established that the Weibull distribution parameters ( $\beta$ and $\eta$ ) show the different dependences on the heating rate of the system $\left(v_{h}\right)$ (shape parameter $(\beta)$ - linear form and scale parameter ( $\eta)$ - exponential form). Model independent values of the apparent activation energy were calculated using the Friedman's isoconversional method. It was found that the calculated apparent activation energy depends on the degree of conversion, $\alpha$, and it shows a constant value in the range of the degree of conversion $0.20 \leq \alpha \leq 0.60\left(E_{a}=90.8 \mathrm{~kJ} \mathrm{~mol}\right.$ $\left.{ }^{1}\right)$. Knowing the Weibull distribution function of reaction times, it is possible to determine the density distribution function of apparent activation energies at different heating rates. It was established that the changes of the symmetry of density distribution functions may be an indication for deviations from the simple crystallization kinetics as expressed by the Johnson-Mehl-Avrami (JMA) model, and this behaviour is probably due to a more complex transformation process such as a process described by the two-parameter autocatalytic Šesták-Berggren model.

Ključne reči: nickel oxide; non-isothermal reduction; apparent activation energy; density distribution functions; true compensation effect.

ACKNOWLEDGEMENTS:The authors would like to thank the Ministry of Science and Environmental Protection of the Republic of Serbia for the financial support of this research under Projects 172015 (Bojan Ž. Janković) and III43009 (Marija M. Janković). The authors also wish to thank Prof. Dr Slavko Mentus (corresponding member of the Serbian Academy of Sciences (SANU)) for supplying the experimental samples and for performing thermo-analytical measurements. 


\section{Introduction}

Metal oxides are widely used as catalysts in environmental chemistry and commercial processes that deal with the conversion of hydrocarbons (Kung, 1989). Thus, oxide catalysts are useful in the destruction of $\mathrm{SO}_{2}$ and $\mathrm{NO}_{x}$ species produced during the combustion of fuels in automobiles, factories and power plants. By preventing the emission of $\mathrm{SO}_{2}$ and $\mathrm{NO}_{x}$ into the atmosphere, they help to minimize the negative effects of acid rain on the entire environment (Kung, 1989), (Stern, et al, 1984). The selective oxidation, ammoxidation and dehydrogenation probably constitute the most important industrial applications of oxide catalysts active for the conversion of hydrocarbons (Kung, 1989). Over the years, there has been a considerable interest in obtaining a fundamental understanding of phenomena responsible for a good performance of oxide catalysts (Kung, 1989), (Henrich, Cox, 1994), (Freund, 1999, pp.1-31).

In most cases, pure stoichiometric oxides do not exhibit a high catalytic activity (Kung, 1989). For the preparation of active oxide catalysts, the partial reduction of nickel oxide under hydrogen at elevated temperatures is the effective method for this preparation (Delmon, 1997), (Furstenau, et al, 1985, p.55), (Lescop, et al, 2004, p.83) In previous studies, two different kinetic models have been proposed for the reduction of metal oxides: 1) nucleation model (Furstenau, et al, 1985, p.55), Langel, 1985, p.543) and 2) interface-controlled model (Delmon, 1969).

The first reported systematic measurement of bulk $\mathrm{NiO}$ reduction was by Benton and Emmett (Benton, Emmett, 124, p.2728). These authors measured water formation as an indication of the extent of reaction for a sample of $\mathrm{NiO}$ made by heating nickel nitrate at $400{ }^{\circ} \mathrm{C}$. They came up with some very important conclusions such as: a) reduction occurs at the interface between $\mathrm{NiO}$ and previously reduced $\mathrm{Ni}$; b) there is an "autocatalytic" effect; c) there is an induction (i.e. nucleation) period that depends on the nature of the sample and temperature, and d) added water reduces the reduction rate and increases the induction period. Koga and Harrison reviewed general reactions between solids and hydrogen and represented the induction process as a generation of nickel atoms on the outer surface of $\mathrm{NiO}$ grains (Koga, Harrison, 1984). Following nucleation, $\mathrm{Ni}$ clusters grow two-dimensionally across the surface until they overlap, at which point hydrogen rapidly dissociates into $\mathrm{Ni}$ and the interface proceeds quikly into the grain (Koga, Harrison, 1984). Bandrowski et al. (Bandrowski, Bickling, Yang, Hougen, 1962, p.379) ured water produced during the reduction to generate sigmoidal conversion curves which they explained with a two-step kinetic model. The first step, the reaction between $\mathrm{NiO}$ and hydrogen atoms adsorbed on $\mathrm{NiO}$, predominates in the early part of the reduction and is proportional to the square root 
of the hydrogen pressure. The second step is the reaction at the metaloxide interface between $\mathrm{NiO}$ and hydrogen atoms adsorbed on the previously reduced $\mathrm{NiO}$. The above models emphasized the chemical mechanism and kinetics of the reduction process, but there was little uniformity in the physical properties of $\mathrm{NiO}$ grains and pellets used. $\mathrm{Ne}-$ vertheless, it was suspected that morphological factors were just as important as topological properties in determining the course of the reduction. These factors were demonstrated by (Moriyama, Yamaguchi, 1964, p.831) who found that reduction rate constants were inversely proportional to a grain size above a diameter of about $10 \mu \mathrm{m}$. Such dependence is predicted by the shrinking core model (Yagi, Kunii, 1955). (Richardson, et al, 1994, p.217) conducted a series of experiments using isothermal $\mathrm{H}_{2}$ consumption and magnetization measurements to determine the $\mathrm{Ni}-\mathrm{O}$ bond rupture (NiO conversion) and the growth of nucleated $\mathrm{Ni}$ atoms, respectively. They found the growth process lagged $\mathrm{NiO}$ conversion by a time interval that increased with decreasing temperature, lower gas flow rates and the presence of $\mathrm{H}_{2} \mathrm{O}$ added to the reducing gas. (Rodriguez, et al, 2002, pp.346-54) showed that in the experiments with a $\mathrm{NiO}(100)$ crystal and $\mathrm{NiO}$ powders, oxide reduction is observed at atmospheric pressures and elevated temperatures $\left(250-350{ }^{\circ} \mathrm{C}\right)$, but only after an induction period. These authors showed that the presence of $\mathrm{O}$ vacancies leads to an increase in the adsorption energy of $\mathrm{H}_{2}$ and substantially lowers the energy barrier associated with the cleavage of the $\mathrm{H}-\mathrm{H}$ bond. (Richardson, et al, 2003, pp.137-150) studied the hydrogen reduction of porous bulk $\mathrm{NiO}$ particles with in situ hot-stage X-ray diffraction (XRD) in the temperature range from 175 to $300{ }^{\circ} \mathrm{C}$. The results obtained by these authors indicated that the reduction in the absence of water added to the reducing gas ocurred in several steps: 1) an induction period associated with the initial reduction of $\mathrm{NiO}$ and the appearance of Ni metal clusters; 2) acceleration of the reduction rate as the size of the clusters increase, and 3) a pseudo-first-order process in which $\mathrm{NiO}$ disappeared and $\mathrm{Ni}$ appeared in concert until the reduction slowed at a fractional conversion of about 0.8 . When $2.2 \times 10^{-2}$ atm of $\mathrm{H}_{2} \mathrm{O}$ was added to the reducing gas, induction times increased by approximately a factor of two and reduction rates decreased, with an apparent activation energy of $126 \pm 27 \mathrm{kJmol}^{-1}$ compared to $85 \pm 6 \mathrm{kJmol}^{-1}$ without added water (Richardson, et al, 2003 , pp.137-150). (Utigard, et al, 2005, p.2061) investigated the reduction kinetics of $\mathrm{NiO}$ granules formed by vapour deposition from a chloride solution, using thermal gravimetry. They reported that, in the temperature range from 400 to $600{ }^{\circ} \mathrm{C}$, the rate of reduction increased with increasing temperature and increasing hydrogen pressure. The microscopic analysis showed that in this temperature range the reaction followed the shrinking core model (Utigard, et al, 2005, p.2061). The same authors 
found that the activation energy for the reduction process has a value of $90 \mathrm{kJmol}^{-1}$, in the above temperature range.

In our previous studies of the temperature-programmed reduction (TPR) of nickel oxide under hydrogen atmosphere, the kinetic scheme of this process was established (Janković, et al, 2007, pp.48-55), (Janković, et al, 2008, p.567). It was concluded that the reduction of $\mathrm{NiO}$ using hydrogen is a multistep mechanism and can be described by the two-parameter autocatalytic Šesták-Berggren (SB) reaction model (Janković, et al, 2007, pp.48-55), (Janković, et al, 2008, p.567). The differential and integral isoconversional methods were used to yield dependency of the apparent activation energy $\left(E_{a}\right)$ for the considered reduction process on the degree of conversion ( $\alpha$ ) (Janković, et al, 2007, pp.48-55), (Janković, et al, 2008, p.567). It was established that the values of $E_{a}$ for a range of $0.20 \leq \alpha \leq 0.60$ were constant and independent on a values. For the temperature-programmed reduction of nickel oxide in hydrogen atmosphere, the following kinetic triplet was obtained: $E_{a}=96.4$ $\mathrm{kJmol}^{-1}, A=1.04 \times 10^{8} \mathrm{~min}^{-1}$ and $f(\alpha)=\alpha^{0.63}(1-\alpha)^{1.39}$ (SB - reaction model).

(Burnham, Braun, 1999, p.1) have discussed the problems of characterizing the range of reactivity inherent in complex materials such as polymers, minerals, fossil fuels, and biochemical materials. For such systems, the distributed reactivity caused by the complexity of the reaction can be modeled by a set of concurrent reactions, each with its characteristic pre-exponential factor and apparent activation energy. One extreme of the model would be where there is no relationship at all between the values of $A$ and of $E_{a}$. Simplifying assumptions includes the following: a) a compensation type of the relationship with $\ln A$ being a linear function of $E_{a}$, b) a single common value of $A$ and a continuous distribution of $E_{a}$ 's, and c) a single common value of $E_{a}$ and a continuous distribution of pre-exponential factors. Burnham and Braun (Burnham, Braun, 1999, p.1) discuss, with examples, the types of distribution which may be continuous or discrete. They report that the most versatile model for distributed reactivity has a discrete distribution of $E_{a}$ 's, and they suggest that, for the greatest accuracy over the initial and final stages of the reaction, the assumption of a uniform pre-exponential factor be replaced by $\ln A$ being a linear function of $E_{a}$.

In this paper, the new procedure for determining the density distribution functions of the apparent activation energies ( $\mathrm{ddf} E_{a}$ 's) (which can correspond to active sites reactivity distributions at different temperatureprogrammed rates) for a non-isothermal reduction process of nickel oxide under hydrogen atmosphere was established. The Weibull probability function (Weibull, 1951, pp.293-297) was used in the evaluation of $\operatorname{ddf} E_{a}$ 's at different heating rates of the system. The established ddf $E_{a}$ 's at all heating rates are the consequence of the complex behavior of $E_{a}$ on $\alpha$, which follows from the sigmoidal autocatalytic Sesták-Berggren reaction model (Janković, et al, 2007, pp.48-55), (Janković, et al, 2008, 
p.567). The aim of this work is to confirm the kinetic model and the reaction scheme for a reduction process of nickel oxide under non-isothermal conditions and calculate the $\operatorname{ddf} E_{a}$ 's which occurs as a consequence of the presence of active nucleation sites with different activation energies.

\section{Materials and experimental details}

The NiO samples were obtained by the gel-combustion method described elsewhere ((Janković, et al, 2007, pp.48-55), (Janković, et al, 2008, p.567), (Mentuš, et al, 2005, pp.345-350)]. A green-colored transparent gel was obtained by drying an aqueous solution of nickel nitrate hexahydrate (Sigma Aldrich, 99.5\%) and citric acid (Sigma Aldrich, 99.5\%), dissolved in a mole ratio $1.8: 1$. This gel further underwent to a self-ignition by heating in air up to $300{ }^{\circ} \mathrm{C}$, and by an additional heating up to $500{ }^{\circ} \mathrm{C}$ which produce very fine nickel oxide powders. The mean size of nickel oxide particles, determined from XRD data is $d_{m}=30 \mathrm{~nm}$, and this value overlaps very well with the data published by (Wu, et al, 2007, p.3174).

The thermo-analytical experiments were carried out in a TA SDT 2960 device, capable of a simultaneous TGA-DTA analysis in the temperature range from $25^{\circ} \mathrm{C}$ to $1500{ }^{\circ} \mathrm{C}$. The nickel oxide samples were reduced directly within the thermo-balance, in a korund pans, under (99.9995 vol \%) hydrogen flowing at a rate of $100 \mathrm{mLmin}^{-1}$, and using various heating rates: 2.5, 5, 10 and $20{ }^{\circ} \mathrm{Cmin}^{-1}$, in the temperature range from an ambient one up to $500{ }^{\circ} \mathrm{C}$. The sample mass used for thermogravimetric investigations was about $25 \pm 0.5 \mathrm{mg}$ (Janković, et al, 2007, pp.48-55). The degree of conversion ( $\alpha$ ) of the reduction process is expressed as:

$$
\alpha=\frac{m_{0}-m_{t}}{m_{0}-m_{f}}
$$

where $m_{0}, m_{t}$ and $\mathrm{m}_{f}$ refer to the initial, actual and final mass of the investigated sample.

\section{Methods used in the determination of the kinetic parameters of the reduction process}

Kissinger method

The basic assumption for this method is that the maximum conversion rate of a single step reaction is independent of the heating rate $\left(v_{h}\right)$ (Kissinger, 1956, p.217), (Kissinger, 1957, pp.1702-6). When plotting the logarithm of $\left(v_{h} / T_{\text {max }}^{2}\right)$ versus the reciprocal absolute temperature of the 
maximum rate, a line is obtained and its slope is proportional to the apparent activation energy $\left(E_{a}\right)$ (Kissinger, 1957, pp.1702-6):

$$
\ln \left(\frac{v_{h}}{T_{\max }^{2}}\right)=\ln \left(\frac{A R}{E_{a}}\right)-\frac{E_{a}}{R T_{\max }}
$$

This method gives a single $E_{a}$ value and cannot detect reaction complexities (Vyazovkin, Wight, 1999, p.53). Eq. (2) is exact for both first order (Kissinger, 1956, p.217) and $n$ th-order reactions (Kissinger, 1957, pp.1702-6) and is an excellent approximation for the nucleation (Chen, et al, 1993, p.109) and distributed reactivity models (Braun, Burnham, 1987, p.153).

\section{Stationary point (SP) method}

In the heterogeneous chemical reaction kinetics, the function $\mathrm{da} / \mathrm{d} t=$ $f(T)$ (where $\mathrm{d} \alpha / \mathrm{d} t$ is the rate of the process and $T$ is the absolute temperature), which has the zero-initial rate, can be observed as a function with a local maximum. This maximum appears in the so-called stationary point: $S\left[(\mathrm{~d} \alpha / \mathrm{d} t)_{\max } ; T_{\max }\right]\left(T_{\max }\right.$ is the temperature at the maximum rate of the process $(d \alpha / d t)_{\max }$ ), where $\left(d^{2} \alpha / d t^{2}\right)=0$ (Klarić, et al, 1995, pp.13731380). Consequently, the stationary point is defined as a point in which the reaction system, under given conditions, has the maximum reaction velocity. In that case, the following equation is valid:

$$
\left(\frac{d \alpha}{d t}\right)_{\max }=k\left(T, p_{j}\right) f\left(\alpha_{\text {max }}\right)
$$

where $(\mathrm{d} \alpha / \mathrm{d} t)_{\max }$ is the maximum velocity of the considered reaction or process, $k\left(T, p_{j}\right)$ is the temperature and partial pressure dependent rate constant, $f\left(\alpha_{\max }\right)$ is a function of the reaction mechanism, $\alpha_{\max }$ is the degree of conversion at $T=T_{\max }$, and $p_{j}$ denotes the partial pressure of the gaseous products. For the non-isothermal conditions, when the temperature varies with time with a constant heating rate $\left(v_{h}\right), v_{h}=\mathrm{d} T / \mathrm{d} t$, Eq. (3) can be written in the form:

$$
\left[v_{h}\left(\frac{d \alpha}{d T}\right)_{\max }\right]=k\left(T, p_{j}\right) f\left(\alpha_{\max }\right) .
$$


If Arrhenius dependence of $\left(k\left(T, p_{j}\right)\right)$ on temperature is supposed, than Eq. (4) can be transformed into the following form:

$$
\left[v_{h}\left(\frac{d \alpha}{d T}\right)_{\max }\right]=A \exp \left(-\frac{E_{a}}{R T_{\max }}\right) f\left(\alpha_{\max }\right)
$$

where $E_{a}$ is the apparent activation energy of the overall process, whereas $A$ and $R$ are the pre-exponential factor and the gas constant, respectively. Since the logarithmic form of Eq. (5) is:

$$
\ln \left[v_{h}\left(\frac{d \alpha}{d T}\right)_{\max }\right]=\ln \left[A f\left(\alpha_{\max }\right)\right]-\frac{E_{a}}{R T_{\max }}
$$

and from the slope of the dependence between $\ln \left[v_{h}(\mathrm{~d} \alpha / d T)_{\max }\right]$ and $1 / T_{\max }$, it is a possible to determine the single value of the apparent activation energy $E_{a}$ of the investigated process. The method of the stationary point does not enable direct calculation of the pre-exponential factor $(A)$. The value of the pre-exponential factor $(A)$ can be determined only in the case when the exact mathematical form of the function $f\left(\alpha_{\max }\right)$ is known (Klarić, et al, 1995, pp.1373-1380).

\section{Friedman method}

The Friedman method (Friedman, 1963, p.183) represent the differential isoconversional (model-free) method, based on the following equation:

$$
\ln \left[v_{h, i}\left(\frac{d \alpha}{d T}\right)_{\alpha, i}\right]=\ln \left[A_{\alpha} f(\alpha)_{i}\right]-\frac{E_{a, \alpha}}{R T_{\alpha, i}}
$$

where the subscripts $i$ and $\alpha$ designate the given values of the heating rate and the degree of conversion, respectively. For a considered $\alpha=$ const., the plot $\ln \left[v_{h, i}(\mathrm{~d} \alpha / \mathrm{d} T)_{\alpha, j}\right]$ versus $\left(1 / T_{\alpha, i}\right)$ should be a straight line whose slope can be used to evaluate the apparent activation energy.

\section{Results and discussion}

The experimentally obtained conversion ( $\alpha-T)$ curves at different heating rates for the non-isothermal reduction process of nickel oxide under the hydrogen atmosphere are given in Fig. 1. 


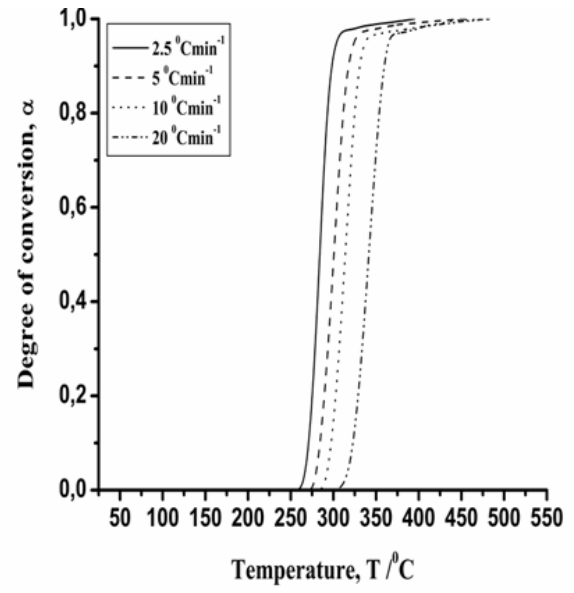

Figure 1 - Non-isothermal conversion ( $\alpha$ vs. T) curves for the reduction process of nickel oxide samples prepared by the gel-combustion method under linearly rising temperature, in hydrogen atmosphere, at the following heating rates $\left(v_{h}\right): 2.5,5,10$ and $20{ }^{\circ} \mathrm{C} \mathrm{min}^{-1}$ Slika 1 - Neizotermne konverzione ( $\alpha$ nasuprot $\mathrm{T}$ ) krive za redukcioni proces uzoraka nikl- oksida, pripremljenih metodom gel-sogorevanja pod linearnim porastom temperature, $u$ atmosferi vodonika, na sledećim brzinama zagrevanja $\left(v_{h}\right): 2,5,5,10$ i $20^{\circ} \mathrm{C} \mathrm{min}^{-1}$
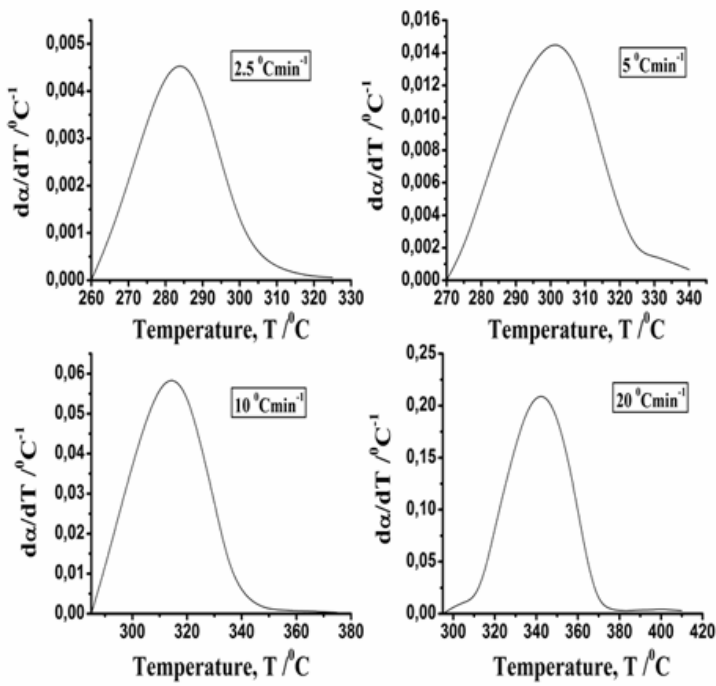

Figure 2 - Experimental differential conversion (da/dT vs. T) curves for the reduction process of nickel oxide samples prepared by the gel-combustion method under hydrogen atmosphere, at different heating rates $\left(v_{h}=2.5,5,10\right.$ and $\left.20{ }^{0} \mathrm{Cmin}^{-1}\right)$

Slika 2 - Eksperimentalne diferencijalne konverzione (da/dT nasuprot T) krive za redukcioni proces uzoraka nikl-oksida, pripremljenih metodom gel-sogorevanja pod atmosferom vodonika, na različitim brzinama zagrevanja $\left(v_{h}=2,5,5,10\right.$ i $\left.20^{\circ} \mathrm{C} \mathrm{min}^{-1}\right)$ 
The total mass-change of $\mathrm{NiO}$ samples at all considered heating rates is about $21.4 \%$. It can be observed that the temperature at the beginning of the process $\left(T_{0}\right)$ increases with increasing the heating rate of the system.

The differential conversion curves of $\mathrm{NiO}$ reduction, obtained from the experimental $\alpha-T$ curves at different heating rates are shown in Fig. 2.

Increasing the heating rate leads to the increase of the reduction rate (the minimum rate is observed at $2.5^{\circ} \mathrm{Cmin}^{-1}$ and the maximum rate is observed at $20{ }^{0} \mathrm{Cmin}^{-1}$ - Fig. 2).

The values of temperatures $T_{0}$ and $T_{\max }\left(T_{\max }\right.$ - at which the rate of reduction process has the maximum value $\left.\left((\mathrm{da} / \mathrm{d} T)_{\max }\right)\right)$ and the values of kinetic parameters, $E_{a}$ and $\ln A$, obtained by the Kissinger's and Stationary point (SP) methods, are shown in Table 1.

Table 1 - Values of $\mathrm{T}_{0}, \mathrm{~T}_{\max }$ and corresponding kinetic parameters obtained by Kissinger's (Eq. (2)) and stationary point (SP) (Eq. (6)) methods, at different heating rates for the non-isothermal reduction process of $\mathrm{NiO}$ under hydrogen atmosphere

Tabela 1 - Vrednosti $\mathrm{T}_{0}, \mathrm{~T}_{\max }$ i odgovarajući kinetički parametri dobijeni Kisindžerovom metodom (jednačina (2)) i metodom stacionarne tačke (jednačina (6)), na različitim brzinama zagrevanja za proces neizotermne redukcije $\mathrm{NiO}$ pod atmosferom vodonika

\begin{tabular}{|c|c|c|c|c|c|c|}
\hline $\begin{array}{c}\mathbf{v}_{\mathrm{h}} \\
\rho^{0} \mathrm{Cmin}^{-1}\end{array}$ & $\begin{array}{l}\mathrm{T}_{0} \\
\rho^{0} \mathrm{C}\end{array}$ & $\begin{array}{l}T_{\max } \\
f^{0} \mathrm{C}\end{array}$ & $\begin{array}{c}\ln A, \\
A / \min ^{-1} \text { a }\end{array}$ & $\begin{array}{c}E_{a} \\
/ \mathrm{kJmol}^{-1} \mathrm{a}\end{array}$ & $\begin{array}{c}\ln \left[A f\left(\alpha_{\max }\right)\right] \\
A / \min ^{-1 b}\end{array}$ & $\frac{E_{a}}{/ \mathrm{kJmol}^{-1 \mathrm{~b}}}$ \\
\hline 2.5 & 260 & 285 & & & & \\
\hline 5 & 270 & 300 & 18.11 & 94.7 & 17.81 & 93.7 \\
\hline 10 & 285 & 315 & \pm 1.99 & \pm 1.2 & \pm 2.11 & \pm 1.6 \\
\hline 20 & 295 & 342 & & & & \\
\hline
\end{tabular}

It can be seen from Table 1, that both temperatures $\left(T_{0}\right.$ and $\left.T_{\max }\right)$ increase with an increase of the heating rate, while the values of the kinetic parameters calculated by the stationary point (SP) method are lower than the values of the kinetic parameters calculated by the Kissinger's method. The difference between the values of $E_{a}$ calculated by both kinetic methods is $1 \mathrm{~kJ} \mathrm{~mol}^{-1}$, and this result shows very good agreement in the estimation of the activation parameters for the investigated nonisothermal reduction.

The value of $E_{a}$ obtained by both peak methods for the considered reduction process is in good agreement with a value of $E_{a}$ established in the previous paper using the invariant kinetic parameters (IKP) $\left(E_{a}=96.4\right.$ $\mathrm{kJ} \mathrm{mol}^{-1}$ ) method (Janković, et al, 2007, pp.48-55).

Assuming that the reaction times $(t)$ of the reduction process are randomly distributed by the laws of the Weibull distribution function (Kolar-Anić, et al, 1975, p.663), (Kolar-Anić, Veljković, 1975, p.669), (Cantú, et al, 2011, p.1), and assuming that the value of the Weibull distribution 
function of reaction times is proportional to the degree of conversion ( $\alpha$ ), it can be written:

$$
\alpha(t)=F=1-\exp \left[-\left(\frac{t-\gamma}{\eta}\right)^{\beta}\right], \beta \geq 0, \eta \geq 0, \mathrm{v} \geq 0,
$$

where $F$ is the cumulative Weibull distribution function, $t$ is the time of reaction, $\beta$ is the shape parameter (because it determines the shape of the distribution), $\eta$ is the scale parameter (because it scales the $t$ variable) and $\gamma$ is a third parameter, used to define a suitable zero point. The constant $y$ is called the location parameter. By changing the shape parameter, the Weibull distribution can be made to have many different shapes, from highly skewed like an exponential distribution to nearly bell-shaped like a normal distribution. Eq. (8) represents the three-parameter cumulative Weibull distribution function. In most cases, the location parameter $y$ is equal to zero and in these cases the three-parameter Weibull distribution function is reduced to the two-parameter cumulative Weibull distribution function. The fact that in such cases, the time evolution of the process follows any probability function is ascribed to the non-uniform distribution of the free energies of active centers at the interface where the considered reaction takes place (Kolar-Anić, et al, 1975, p.663), (Kolar-Anić, Veljković, 1975, p.669), (Cantú, et al, 2011, p.1), (Staszczuk, et al, 2002, pp.23-36.

Moreover, in the thermogravimetric analysis, there is a functional relationship between the time $(t)$ and the temperature $(T)$ defined by the selected form of the heating rate. If this relation is linear, as it is in the case considered here,

$$
t=\frac{T-T_{0}}{v_{h}}
$$

where $v_{h}$ is the heating rate, the time dependent degree of conversion, $\alpha(t)$, can be written as a function of temperature such that

$$
\alpha(T) \equiv F(T)=1-\exp \left[-\left(\frac{T-T_{0}-v_{h} \gamma}{v_{h} \eta}\right)^{\beta}\right] .
$$

The last equation is applied for the analysis of the considered results, where $\alpha(T)$ is the degree of conversion of the investigated reduction process at a given heating rate and the relation between time and temperature is the linear. The location parameter $(\gamma)$ is equal to zero in all four cases. Using a linear form of Eq. (10) (the Weibull plot method) (Lin, Berndt, 1995, pp.111-117), given by the following relation: 


$$
\ln [-\ln (1-F(T))]=\beta \ln \left(\frac{1}{\eta}\right)+\beta \ln \left(\frac{T-T_{0}}{v_{h}}\right)
$$

we obtained the results presented in Fig. 3 and in Table 2. The linear realtionship is satisfied in a wide domain of the degree of conversion $(\Delta \alpha=$ 0.06 - 0.96) (in all four cases $r$ is higher than 0.9990) (Table 2).

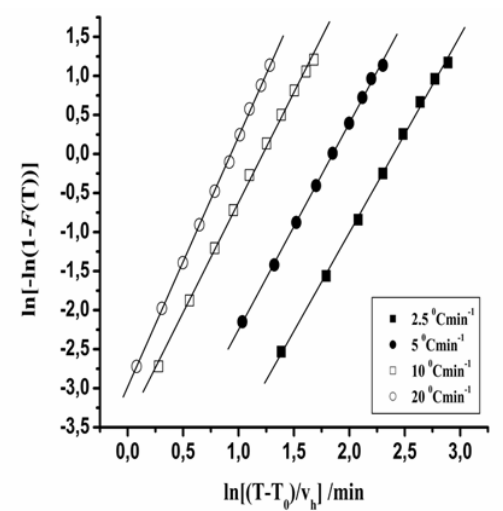

Figure 3 - The Weibull plots for the reduction process of nickel oxide $(\mathrm{NiO})$ under the hydrogen atmosphere at different heating rates $\left(v_{h}\right): 2.5^{0} \mathrm{Cmin}^{-1}(\bullet), 5^{0} \mathrm{Cmin}^{-1}(\bullet), 10$

$$
{ }^{0} \mathrm{Cmin}^{-1}(\square), 20{ }^{0} \mathrm{Cmin}^{-1}(\mathrm{O})
$$

Slika 3 - Vejbulovi grafici za proces redukcije nikl-oksida (NiO) pod atmosferom vodonika na različitim brzinama zagrevanja $\left(v_{h}\right): 2,5^{0} \mathrm{C}_{\mathrm{min}^{-1}}(\boldsymbol{\bullet}), 5^{0} \mathrm{C} \mathrm{min}^{-1}(\bullet), 10^{0} \mathrm{C} \mathrm{min}^{-1}$

$$
\text { (口), } 20^{\circ} \mathrm{Cmin}^{-1}(\circ)
$$

Table 2 - The linear domains of $\alpha(\Delta \alpha)$, the rate constants $(1 / \eta)$ and the Weibull distribution parameters $(\beta$ and $\eta$ ) with $y$ equal to zero, obtained for the reduction process of $\mathrm{NiO}$ using hydrogen at different heating rates, with the corresponding values of $r$ and SD

Tabela 2 - Linearni domeni $\alpha(\Delta \alpha)$, konstante brzina $(1 / \eta)$ i parametri Vejbulove raspode-

\begin{tabular}{|c|c|c|c|c|c|c|}
\hline $\begin{array}{c}\mathrm{V}_{\mathrm{h}} \\
\rho^{0} \mathrm{Cmin}^{-1}\end{array}$ & $\Delta \alpha$ & $\frac{1 / \eta^{-1}}{/ m^{-1}}$ & $\underset{\text { Imin }}{\eta}$ & $\boldsymbol{\beta}$ & $r^{b}$ & $S D^{c}$ \\
\hline 2.5 & $0.08-0.96$ & 0.0907 & $\begin{array}{r}11.03 \\
\pm 0.08\end{array}$ & $\begin{array}{c}2.52 \\
\pm 0.03\end{array}$ & 0.9995 & 0.0467 \\
\hline 5 & $0.11-0.96$ & 0.1576 & $\begin{array}{c}6.34 \\
\pm 0.05\end{array}$ & $\begin{array}{c}2.65 \\
\pm 0.03\end{array}$ & 0.9997 & 0.0317 \\
\hline 10 & $0.06-0.96$ & 0.2954 & $\begin{array}{r}3.38 \\
\pm 0.05\end{array}$ & $\begin{array}{c}2.82 \\
\pm 0.04\end{array}$ & 0.9992 & 0.0545 \\
\hline 20 & $0.06-0.96$ & 0.3940 & $\begin{array}{r}2.54 \\
\pm 0.01 \\
\end{array}$ & $\begin{array}{c}3.20 \\
\pm 0.02\end{array}$ & 0.9998 & 0.0263 \\
\hline
\end{tabular}
le $(\beta$ and $\eta$ ) sa y jednako nuli, dobijeni za proces redukcije NiO korišćenjem vodonika na različitim brzinama zagrevanja, sa odgovarajućim vrednostima r i SD

${ }^{\text {a }}$ The rate constant (Konstanta brzine).

${ }^{\mathrm{b}}$ Linear correlation coefficient (Koeficijent linearne korelacije).

${ }^{\mathrm{c}}$ Standard deviation (Standardna devijacija). 
The obtained values of the shape parameter $(\beta)$ increases with the increase of the heating rate, until the scale parameter $(\eta)$ decreases with the heating rate (Table 2). Also, from the same table, we can see that the shape parameter $(\beta)$, with $\beta>1$ indicates continuous increasing of the reduction rate in respect of increasing the heating rate behaviour. Obviously, the Weibull distribution function can be applied for the analysis of the considered conversion curves (Fig. 1) of the investigated reduction process. The functional relationships between the Weibull distribution parameters $(\beta$ and $\eta)$ and the heating rate $\left(v_{h}\right)$, can be expressed by the following mathematical equations:

$$
\begin{aligned}
& \beta=a+b v_{h} \\
& \eta=c+d \exp \left(-\frac{v_{h}}{\varphi}\right)
\end{aligned}
$$

where the constant $a$ is dimensionless, while the constant $b$ has a dimension [min ${ }^{0} \mathrm{C}^{-1}$ ]. The constants $c$ and $d$ have dimensions of the parameter $\eta$, while the constant $\varphi$ has a dimension of the heating rate, $v_{h}\left[{ }^{0} \mathrm{C}\right.$ $\left.\min ^{-1}\right]$. In the considered case, the values of the corresponding constants are: $a=2.440, b=0.038 \mathrm{~min}^{0} \mathrm{C}^{-1}, c=2.541 \mathrm{~min}, d=18.764 \mathrm{~min}$ and $\varphi=$ $3.147{ }^{\circ} \mathrm{C} \mathrm{min}-1$. The graphical representations of the above functional relationships between the Weibull distribution parameters and the heating rate as the controlling parameter are presented in Figs. 4 and 5.

If the temperature dependence of the degree of conversion $\alpha[(T)]$ is well described by Eq. (10), with the location parameter $y=0$, then the corresponding rate of the reduction process can be given by the first derivative of this function with respect to the temperature. Thus, we can write the following equation:

$$
\frac{d \alpha}{d T}=\frac{\beta}{v_{h} \eta}\left(\frac{T-T_{0}}{v_{h} \eta}\right)^{\beta-1} \exp \left[-\left(\frac{T-T_{0}}{v_{h} \eta}\right)^{\beta}\right] .
$$

Since the time and the temperature are directly correlated by Eq. (9), the rate law equation, expressed through the Weibull (non-isothermal) probability density function (Wpdf) (Eq. (14)), is used for the description of the nickel oxide reduction process by hydrogen under dynamic conditions.

The maximum temperature value $\left(T_{\max }\right)$ which corresponds to the maximum rate can be obtained when the first derivative of Eq. (14) is equal to zero, and this value is given by the following relation:

$$
T_{\max }=v_{h} \eta\left(\frac{\beta-1}{\beta}\right)^{\frac{1}{\beta}}+T_{0} .
$$




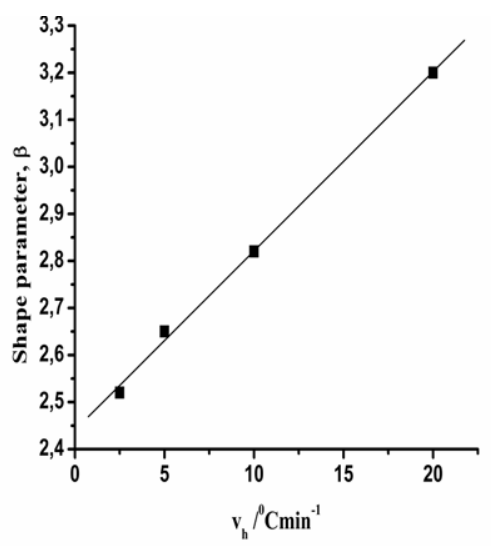

Figure 4 - The linear functional relationship between the Weibull shape parameter $(\beta)$ and the heating rate $\left(\mathrm{v}_{\mathrm{h}}\right)$ (Eq. (12)) for the reduction process of $\mathrm{NiO}$ under hydrogen atmosphere Slika 4 - Linearna funkcionalna veza između Vejbulovog parametra oblika $(\beta)$ i brzine zagrevanja $\left(\mathrm{V}_{\mathrm{h}}\right)$ (jednačina $\left.(12)\right)$ za proces redukcije NiO pod atmosferom vodonika

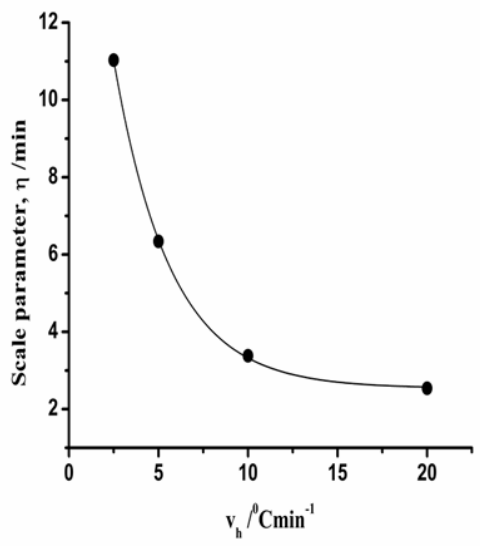

Figure 5 - The exponential relationship between the Weibull scale parameter $(\eta)$ and the heating rate $\left(\mathrm{V}_{\mathrm{h}}\right)$ (Eq. (13)) for the reduction process of $\mathrm{NiO}$ under hydrogen atmosphere

Slika 5 - Eksponencijalna veza između Vejbulovog skalarnog parametra $(\eta)$ i brzine zagrevanja $\left(v_{h}\right)$ (jednačina (13)) za proces redukcije NiO pod atmosferom vodonika

Fig. 6 shows the comparison between the experimental nonisothermal differential conversion curves and the Weibull probability density functions (Wpdf's) at every considered heating rate, for the reduction process of $\mathrm{NiO}$ under hydrogen atmosphere. For the construction of the Weibull probability density functions (Wpdfs), the values of $\beta$ and $\eta$ parameters from Table 2 were used. 

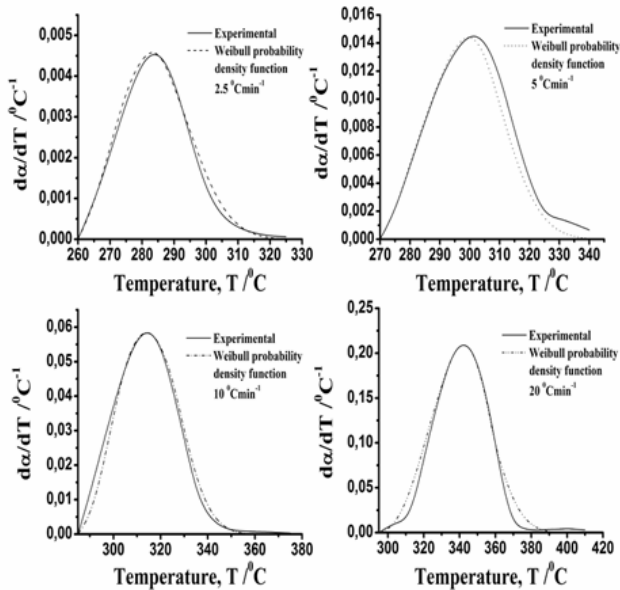

Figure 6 - The comparison of the experimental non-isothermal differential conversion curves and the Weibull probability density functions (Wpdf's) at different heating rates for the reduction process of $\mathrm{NiO}$ using hydrogen

Slika 6 - Poređenje eksperimentalnih neizotermnih diferencijalnih konverzionih krivih i Vejbulovih funkcija gustina verovatnoće (Wpdf's) na različitim brzinama zagrevanja, za proces redukcije $\mathrm{NiO}$ korišćenjem vodonika

It can be seen (Fig. 6) that there is excellent agreement between the experimental differential curves ( $\mathrm{d} \alpha / \mathrm{d} T$ vs $T$ ) and the Weibull probability density functions calculated by Eq. (14) at different heating rates.

It can be observed that the Weibull probability density functions (Wpdf's) (and also the experimental differential rate curves) show the right-skewed behaviour, but the skewness of the Weibull density distribution decreases with the increase of both the heating rate and the Weibull shape parameter $(\beta)$ (see Fig. 6 and Table 2).

Table 3 shows the experimental $T_{\max , \exp }$ and $(\mathrm{d} \alpha / \mathrm{d} T)_{\max , \exp }$ values and also the values of $T_{\max , \mathrm{W}}$ and $(\mathrm{d} \alpha / \mathrm{d} T)_{\max , \mathrm{W}}$ determined from Eq. (15) and Fig. 6, respectively.

Table 3 - The comparison of the experimental (exp) and the calculated (W) (Eq. (15) and

Fig. 6) values of $\mathrm{T}_{\max }$ and (da/dT) $\max$ for the reduction process of $\mathrm{NiO}$ under hydrogen atmosphere at different heating rates

Tabela 3 - Poređenje eksperimentalnih (exp) i izračunatih (W) (jednačina (15) i slika 6) vrednosti $\mathrm{T}_{\max } \mathrm{i}(\mathrm{d} \alpha / \mathrm{dT})_{\max }$ za proces redukcije NiO pod atmosferom vodonika na različitim brzinama zagrevanja

\begin{tabular}{|c|c|c|c|c|}
\hline $1^{0} \mathrm{Cm}_{\mathrm{hin}}^{-1}$ & $T_{\text {max } \exp } I^{\circ} \mathrm{C}$ & $\begin{array}{l}(\mathrm{da} / \mathrm{d} /)_{\operatorname{max,exp}} \\
\quad \mathrm{I}^{0} \mathrm{C}^{-1},\end{array}$ & $\begin{array}{c}T_{\max , \mathrm{w}} \\
\rho^{\circ} \mathrm{C}\end{array}$ & $(\mathrm{da} / \mathrm{d} T)_{\max , \mathrm{w}} /^{0} \mathrm{C}^{-1}$ \\
\hline 2.5 & 285 & 0.00453 & 282.6 & 0.00457 \\
\hline 5 & 300 & 0.01444 & 296.5 & 0.01439 \\
\hline 10 & 315 & 0.05821 & 314.0 & 0.05825 \\
\hline 20 & 342 & 0.20901 & 340.2 & 0.20932 \\
\hline
\end{tabular}


As it can be seen in Table 3, the values of $T_{\max , \mathrm{W}}$ and $(\mathrm{da} / \mathrm{d} T)_{\max , \mathrm{W}}$ based on the Weibull distribution are very similar to the experimental va-

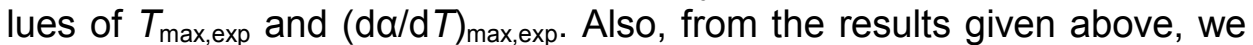
can see that the experimental differential rate curve at $20{ }^{0} \mathrm{Cmin}^{-1}$ can be very sucessfully approximated with the Weibull probability density functions with $\beta=3.20$, which corresponds with a highly symmetrical function, as the normal distribution function (Plait, 1962, p.17), (Anthony, Howard, 1976, pp.625-656 ), (Campbell, et al, 1980, p.727).

If we introduce the values of $T_{\text {max }, W}$ (Table 3 ) in Kissinger's equation (Eq. (2)), we can obtain the kinetic parameters $\left(\ln A_{w}\right.$ and $\left.E_{a, w}\right)$, which are calculated on the basis of Eq. (15). In this case, the positions of $T_{\max , \mathrm{W}}$ are governed by the values of the Weibull distribution parameters ( $\beta$ and $\eta$ ) and the temperature $T_{0}$. The values of $\ln A_{\mathrm{w}}$ and $E_{a, \mathrm{w}}$ obtained from Eq. (2) for $T_{\max , \mathrm{w}}$, at different heating rates are: $\ln A_{\mathrm{W}}=17.58 \pm 1.77\left(A_{\mathrm{W}}\right.$ expressed in $\mathrm{min}^{-1}$ ) and $E_{a, \mathrm{~W}}=92.0 \pm 1.0 \mathrm{~kJ} \mathrm{~mol}^{-1}$. The calculated values of $\ln A_{W}$ and $E_{a, w}$ are in very good agreement with the values of $\ln A$ and $E_{a}$ evaluated for the experimental temperatures $T_{\text {max }}$.

Since we have shown above that the experimentally obtained differential rate curves are well fitted by the Weibull distribution function, we can also calculate the apparent activation energies at different values of $\alpha$. For this purpose, the differential isoconversional method was applied.

The values of the apparent activation energies $\left(E_{a}\right)$ at different constant values of $\alpha$, which was determined by the Friedman's method, are shown in Fig. 7.

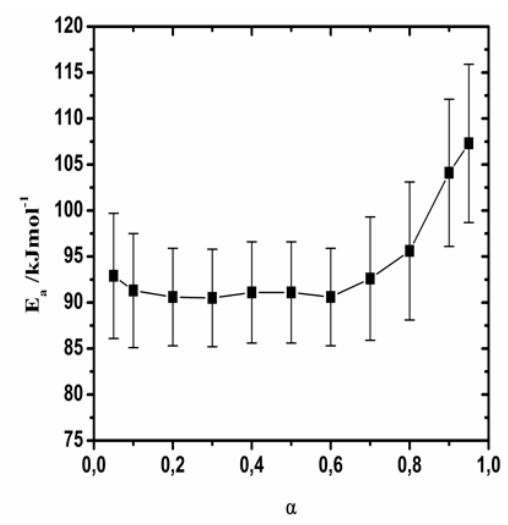

Figure 7 - The dependence of the apparent activation energy $\left(E_{a}\right)$ of the degree of conversion ( $\alpha$ ) determined using the differential isoconversional method for the reduction process of nickel oxide $(\mathrm{NiO})$ under hydrogen atmosphere

Slika 7 - Zavisnost prividne energije aktivacije $\left(E_{a}\right)$ od stepena konverzije ( $\alpha$ ) određena korišćenjem diferencijalne izokonverzione metode za proces redukcije nikl-oksida (NiO) pod atmosferom vodonika 
Within the limits of the experimental errors in the determination of $E_{a}$ 's by the Friedman's method, the apparent activation energy of the $\mathrm{NiO}$ reduction process in the range of $0.20 \leq \alpha \leq 0.60$ is practically a constant value, independent of $\alpha$ values $\left(E_{a}=90.8 \mathrm{~kJ} \mathrm{~mol}^{-1}\right)$.

For $0.05 \leq \alpha \leq 0.20$ the values of $E_{a}$ decrease, while for $\alpha \geq 0.60$ the values of $E_{a}$ increase with the increase of $\alpha$ values. The existence of the "plateau" in Fig. 7, in the wide range of the degree of conversion ( $\alpha)$, confirms the occurrence of the single-step reaction (Janković, et al, 2007, pp.48-55).

The increase of $E_{a}$ values when increasing $\alpha$, for $\alpha \geq 0.60$, pointed to the existence of a parallel independent reaction (Janković, et al, 2007, pp.48-55), (Vyazovkin, et al, 1992, p.41), which possessed a higher value of the apparent activation energy and whose part in the overall process increased in the considered range of $\alpha$.

It was shown (Koga, 1994, p.1), (Budrugeac, Segal, 1995, p.33), (Vyazovkin, Linert, 1995, p.355), (Vyazovkin, Linert, 1995, p.109) that if $E_{a}$ and $A$ depend on $\alpha$, the kinetic parameters are correlated through the relation of the compensation effect (Agrawal, 1986, pp.73-86), (Galwey, 1977, p.247):

$$
\ln A_{\xi}=a+b E_{a, \xi}
$$

where $a$ and $b$ are the compensation constants and the subscript $\xi$ refers to a factor that produces a change in kinetic parameters. Thus, if $E_{a}$ depends on $\alpha$, the Friedman's method (Friedman, 1963, p.183), which uses directly the equation of the reaction rate, is recommended.

Analyzing the mutual interdependence of kinetic parameters (for the differential isoconversional method (Friedman, 1963, p.183), this is $A_{\alpha} f(\alpha)$ and $E_{a, \alpha}$ ) at the same degree of conversion, it was found that the following linear relationship is satisfied for every considered $\alpha$ :

$$
\ln \left[A_{\alpha} f(\alpha)\right]=-1.3625+0.2085 E_{a, \alpha},
$$

where the obtained values of compensation constants for the reduction process of $\mathrm{NiO}$ under hydrogen atmosphere are: $a=-1.3625$ and $b=$ $0.2085 \mathrm{~mol} \mathrm{~kJ}^{-1}$. According to the literature (Agrawal, 1986, pp.73-86) this is a confirmation of a true compensation effect in the cases when the dependence of $\ln A$ versus $E_{a}$ is linear. A necessary condition for a compensation effect to be true (or real) is the ability of the $\xi$ factor to affect the temperature dependence of the reduction rate (Vyazovkin, Wight, 1997, pp.125-49). Obviously, for the investigated non-isothermal reduction process of $\mathrm{NiO}$ under hydrogen atmosphere, the role of $\xi$ factor has a conversion ( $\alpha)$ (Fig. 7) and the heating rate $\left(v_{h}\right)$.

If we choose, for the differential conversion function $(f(\alpha))$, the twoparameter Šesták-Berggren (SB) kinetic model, with average values of 
kinetic exponents $(m=0.63, n=1.39)$ calculated in our previous papers (Janković, et al, 2007,pp.48-55), (Janković, et al, 2008, p.567), the linear dependence of $\ln A$ versus $E_{a}$ for nickel oxide reduction can be obtained (introducing the SB function, $f(\alpha)=\alpha^{m}(1-\alpha)^{n}$ in Eq. (17)) (Fig. 8).

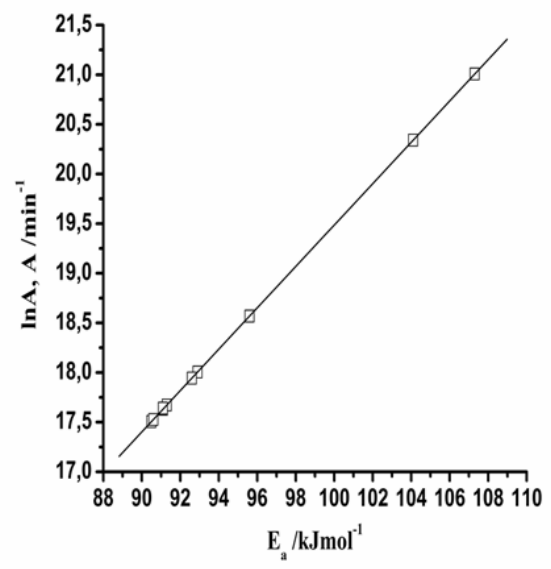

Figure 8 - The true compensation effect (InA vs. $E_{a}$ ) evaluated from the isoconversional Friedman's method, for the reduction process of $\mathrm{NiO}$ under hydrogen atmosphere

Slika 8. - Istiniti kompenzacioni efekat (InA naspram $\mathrm{E}_{\mathrm{a}}$ ) izveden iz izokonverzione Fridmanove metode za proces redukcije NiO pod atmosferom vodonika

Furthermore, using Eq. (9), we can now obtain the time dependent relation for the apparent activation energies, evaluated for every constant value of $\alpha$. The numerically fitted relation between the reaction time and the apparent activation energy is given by the expression:

$$
t=t_{0}+t_{1} \ln \frac{\left(E_{a}-E_{0}\right)}{\varepsilon}
$$

where $t_{0}, t_{1}, E_{0}$ and $\varepsilon$ are the fitting coefficients. The coefficients $E_{0}$ and $\varepsilon$ must have the dimensions of energy, whereas $t_{0}$ and $t_{1}$ have the dimensions of time. The fitting coefficient $E_{0}$ corresponds to the threshold activation energy value for the investigated reduction process (Table 4), while the coefficients $t_{0}, t_{1}$ and $\varepsilon$ represent the "solid" constants and they do not have any physical meaning. For finding the mathematical relationship between the reaction time and the apparent activation energy, the values of $E_{a}$ calculated by the Friedman's method at different $\alpha$ 's were used. 
The influence of the heating rate $\left(v_{h}\right)$ on the values of the fitting coefficients $t_{0}, t_{1}$ and $\varepsilon$ is shown in Table 4 . The values of $E_{0}$ at every particular heating rate of the considered system are also presented in Table 4.

Table 4 - The influence of the heating rate $\left(v_{h}\right)$ on the values of the fitting coefficients $\left(t_{0}\right.$, $t_{1}$ and $\varepsilon$ ) and the threshold activation energy $\left(E_{0}\right)$, for the non-isothermal reduction process of nickel oxide samples prepared by the gel-combustion method, under hydrogen atmosphere

Tabela 4 - Uticaj brzine zagrevanja $\left(v_{h}\right)$ na vrednosti koeficijenata fitovanja $\left(t_{0}, t_{1}\right.$ i $\left.\varepsilon\right)$ i početne energije aktivacije $\left(E_{0}\right)$, za neizotermni proces redukcije uzoraka nikl-oksida pripremljenih putem metode sol-sagorevanja, pod atmosferom vodonika

\begin{tabular}{|c|c|c|c|c|}
\hline$I^{0} \mathrm{C} \mathrm{min}^{\mathrm{V}_{\mathrm{h}}}$ & $\begin{array}{c}t_{0} \\
/ \mathrm{min}\end{array}$ & $\begin{array}{c}t_{1} \\
/ \mathrm{min}\end{array}$ & $\begin{array}{c}\boldsymbol{\varepsilon} \\
/ \mathrm{kJ} \mathrm{mol}^{-1}\end{array}$ & $\begin{array}{c}E_{0}{ }^{\mathrm{a}} \\
/ \mathrm{kJ} \mathrm{mol}{ }^{-1}\end{array}$ \\
\hline 2.5 & $\begin{array}{c}0.16 \\
\pm 0.02\end{array}$ & $\begin{array}{c}3.40 \\
\pm 1.01\end{array}$ & $\begin{array}{c}0.12 \\
\pm 0.08\end{array}$ & $\begin{array}{l}90.2 \\
\pm 1.4\end{array}$ \\
\hline 5 & $\begin{array}{c}0.21 \\
\pm 0.01\end{array}$ & $\begin{array}{c}1.95 \\
\pm 0.02\end{array}$ & $\begin{array}{c}0.15 \\
\pm 0.07\end{array}$ & $\begin{array}{r}90.2 \\
\pm 0.7\end{array}$ \\
\hline 10 & $\begin{array}{c}0.13 \\
\pm 0.04\end{array}$ & $\begin{array}{c}1.01 \\
\pm 0.03\end{array}$ & $\begin{array}{c}0.12 \\
\pm 0.08\end{array}$ & $\begin{array}{r}90.2 \\
\pm 1.3\end{array}$ \\
\hline 20 & $\begin{array}{c}0.17 \\
\pm 0.01 \\
\end{array}$ & $\begin{array}{c}0.46 \\
\pm 0.01 \\
\end{array}$ & $\begin{array}{c}0.02 \\
\pm 0.00 \\
\end{array}$ & $\begin{array}{r}90.2 \\
\pm 1.1 \\
\end{array}$ \\
\hline
\end{tabular}

${ }^{a}$ The same characteristic value for $E_{0}$ (Ista karakteristična vrednost za $E_{0}$ ).

The value of the fitting coefficient $t_{0}$ increases with an increase of the heating rate from 2.5 to $5{ }^{\circ} \mathrm{C} \mathrm{min}{ }^{-1}$ and then decreases with an increase of the heating rate fom 5 to $10^{\circ} \mathrm{C} \mathrm{min}-1$. With an increase of the heating rate from 10 to $20^{\circ} \mathrm{C} \mathrm{min}^{-1}$, the coefficient $t_{0}$ increase again. On the other hand, the value of the fitting coefficient $t_{1}$ decreases with an increase of the heating rate. The value of the fitting coefficient $\varepsilon$ increases with an increase of the heating rate from 2.5 to $5{ }^{\circ} \mathrm{C} \mathrm{min}{ }^{-1}$ and then decreases from 5 to $20{ }^{0} \mathrm{C} \mathrm{min}^{-1}$. The value of the threshold activation energy is the same at all considered heating rates (the characteristic value of 90.2 $\mathrm{kJmol}^{-1}$ ) (see Table 4).

The time dependence of the apparent activation energies can appear in very complex reaction systems or in a simple system where there is an energy distribution of active centers. In the last case, we have the sum of parallel reactions that differ only in the values of apparent activation energies and consequently in corresponding rate constants (Lakshmanan, et al, 1991, p.110), (Lakshmanan, White, 1994, p.1158), (Miura, Maki, 1998, p.864), (Mcguinness, et al, 1999, p. 27), (Burnham, et al, 2004, p.19432), (Burnham, 2005, p.47). Their effective value of a must depend on the time or temperature (Eq. (9)) in a complex manner. Such dependence between a and temperature is already given by Eq. (14). 
Our next aim is to obtain the density distribution functions of the apparent activation energies (ddfE's) at different heating rates $\left(v_{h}\right)$ for the investigated reduction process.

It should be pointed out that in the earlier studies, (Shih, Sohn, 1980, p.420) and (Braun, Burnham, 1987, p.153) clarified that the conversion-dependent $E_{a}$ values obtained by the Friedman's method result from the distribution of the apparent activation energy. In accordance with the above-mentioned discussion, in order to determine the ddf $E_{a}$ 's (designates by $p\left(E_{a}\right)$ ), we need to write Eq. (14) in a function of the reaction time as:

$$
\frac{d \alpha}{d t}=\frac{\beta}{\eta}\left(\frac{t}{\eta}\right)^{\beta-1} \exp \left[-\left(\frac{t}{\eta}\right)^{\beta}\right],
$$

and find $p\left(E_{a}\right)=d \alpha / d E_{a}$, using the following relation as:

$$
p\left(E_{a}\right)=\frac{d \alpha}{d E_{a}}=\left(\frac{d \alpha}{d t}\right) \times \frac{d t}{d E_{a}} .
$$

From Eq. (18), we can find the term $\mathrm{d} t / \mathrm{d} E_{a}$ :

$$
\frac{d t}{d E_{a}}=\frac{t_{1}}{\left(E_{a}-E_{0}\right)} .
$$

The density distribution functions of the apparent activation energies, $p\left(E_{a}\right)=\mathrm{d} \alpha / \mathrm{d} E_{a}$ are now given in the following form:

$$
\begin{aligned}
& p\left(E_{a}\right)=\frac{\beta}{\eta} \frac{t_{1}}{\left(E_{a}-E_{0}\right)}\left[\frac{t_{0}+t_{1} \ln \frac{\left(E_{a}-E_{0}\right)}{\varepsilon}}{\eta}\right]^{\beta-1} \times \\
& \times \exp \left\{-\left[\frac{\left.t_{0}+t_{1} \ln \frac{\left(E_{a}-E_{0}\right)}{\varepsilon}\right]^{\beta}}{\eta}\right\} .\right.
\end{aligned}
$$

The influence of the heating rate $\left(v_{h}\right)$ on the shape of the density distribution function of the apparent activation energy is shown in Fig. 9. 


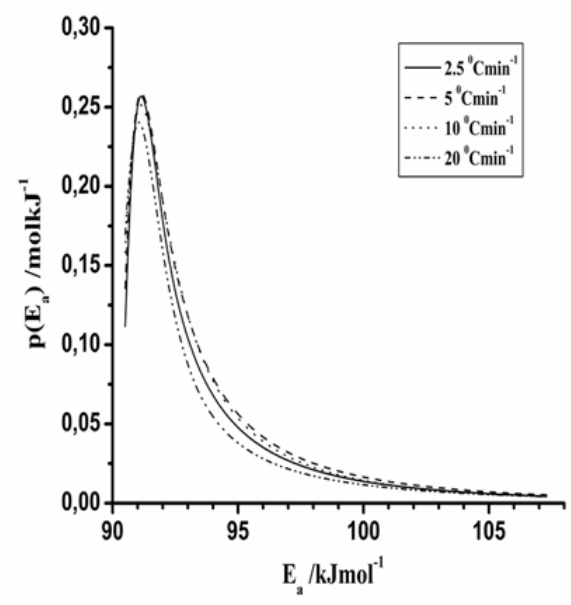

Figure 9 - The influence of the heating rate on the shape and the basic characteristics of the density distribution function of the apparent activation energies $\left(p\left(E_{a}\right)\right.$ was calculated from Eq. (22)), for the non-isothermal reduction process of nickel oxide under hydrogen atmosphere

Slika 9 - Uticaj brzine zagrevanja na oblik i osnovne karakteristike funkcije gustine raspodele prividnih energija aktivacije $p\left(E_{a}\right)$ izračunat je iz jednačine (22), za proces neizotermne redukcije nikl-oksida pod atmosferom vodonika

The basic characteristics of the density distribution functions of the apparent activation energies: $E_{a, \max }$ - the value of the apparent activation energy at the maximum value of the distribution function, $p\left(E_{a}\right)_{\max }-$ the maximum value of the density distribution function, $p\left(E_{\mathrm{a}}\right)_{\mathrm{HW}}$ - the value of the density distribution function on the half-wide, SF - shape factor or the factor of asymmetry and HW - half-wide of the density distribution function, at different heating rates, are presented in Table 5.

From the results in Table 5 and Fig. 9, it follows: a) the density distribution function of apparent activation energies is dependent on the heating rate of the system. This dependence is less declared at lower values of $E_{a}$ i.e. to the value of $E_{a \text {,max }}$, and increases at the higher values of $E_{a}$ (after the value of $E_{a, \max }$ ) (Fig. 9); b) The value of $p\left(E_{a}\right)_{\text {Hw }}$ increases with an increase of the heating rate, $c$ ) Shape factor (SF) increases with an increase of the heating rate (Table 5). The maximum value of SF (1.25) was observed at a higher value of the heating rate (for $20{ }^{\circ} \mathrm{C} \mathrm{min}$ 1); d) The value of half-wide (HW) decreases with an increase of the heating rate (Table 5) and overtakes its own minimum value at $20{ }^{\circ} \mathrm{C} \mathrm{min}{ }^{-1}$ $(\mathrm{HW}<1)$. It can be observed that the value of $E_{a, \max }$ (at all heating rates) is very similar to the value of $E_{a}$ calculated using the differential isoconversional method $\left(90.8 \mathrm{~kJ} \mathrm{~mol}^{-1}\right)$. 
Table 5 - The influence of the heating rate $\left(v_{h}\right)$ on the basic characteristics of the density distribution function of the apparent activation energies (ddfE $\left.E_{a}^{\prime} s\right), p\left(E_{a}\right)$, for the reduction process of nickel oxide under hydrogen atmosphere

Tabela 5 - Uticaj brzine zagrevanja $\left(v_{h}\right)$ na osnovne karakteristike funkcije gustine raspodele prividnih energija aktivacije ( ddfE $_{a}$ 's), $p\left(E_{a}\right)$, za proces redukcije nikl-oksida pod atmosferom vodonika

\begin{tabular}{|c|c|c|c|c|c|}
\hline$I^{0} \mathrm{C}_{\mathrm{min}^{-1}}^{\mathrm{V}_{\mathrm{h}}}$ & $\begin{array}{c}E_{\mathrm{a}, \max } \\
/ \mathrm{kJ}^{-1} \\
\mathrm{~mol}^{-1}\end{array}$ & $\underset{\substack{\rho \mathrm{mol} \\
\mathrm{kJ}^{-1}}}{p\left(E_{\mathrm{a}}\right)_{\max }}$ & 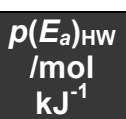 & $\begin{array}{c}\text { Shape fac- } \\
\text { tor, } \\
\text { SF }\end{array}$ & $\begin{array}{c}\text { Half-wide, } \\
\text { HW /kJ } \\
\text { mol }^{-1}\end{array}$ \\
\hline 2.5 & 91.2 & 0.2565 & 0.1843 & 0.6250 & 1.3 \\
\hline 5 & 91.2 & 0.2587 & 0.1972 & 0.7143 & 1.2 \\
\hline 10 & 91.2 & 0.2508 & 0.2047 & 0.8333 & 1.1 \\
\hline 20 & 91.2 & 0.2402 & 0.2051 & 1.2500 & 0.9 \\
\hline
\end{tabular}

For complex processes, global apparent activation energy is often determined, which is a complicated average of the individual reaction steps. The value of $E_{a, \max }$ (Table 5 and Fig. 9) can be correlated with a constant value of $E_{a}$ (observed in Fig. 7) in a wide range of conversions $(0.20 \leq \alpha \leq 0.60)$, which is a consequence of the constant activation energy for crystal growth of $\mathrm{NiO}$ crystallites induced in the nucleation stage of the process whose duration period depends on the heating rate of the system (Janković, et al, 2007, p.48-55). The increasing of $E_{a}$ values (Fig. 7), which corresponds to the right "wing" of the density distributions after the point of $E_{a \text {,max }}$ (Fig. 9) was probably caused by the mutual overlapping of Ni growth crystals, which led to the decreasing of the area size of the boundary phase and the process rate. This reaction step also leads to a continuous decrease of intensity of the density distribution functions at all heating rates (Fig. 9). On the other hand, the heating rate has a considerable influence on some important characteristics of the density distribution function of the apparent activation energy ( $\operatorname{ddf} E_{a}$ ) as a shape factor or a factor of asymmetry (as a shape factor - SF). It can be observed from Table 5, that only for $v_{h}=20{ }^{\circ} \mathrm{C} \mathrm{min}^{-1}$, the density distibution function of the apparent activation energy exhibits the asymmetry factor which is greater than unity (SF $>1$ ), while for other values of $v_{h}$, the ddf $E_{a}$ 's exhibits the asymmetry factor lower than unity (SF $\left.<1\right)$. This behaviour is confirmed from the shapes of experimental da/d $T$ vs. $T$ curves which are very well described by the Weibull probability density functions (Wpdf's). The experimental da/d $T$ vs. $T$ curve at $20{ }^{\circ} \mathrm{C} \mathrm{min}{ }^{-1}$ can be best described by the Wpdf with $\beta=3.20$ which correspond to the symmetrical normal distribution function. It can be pointed out that this change of the symmetry of density functions may be an indication for a deviation from the simple crystallization kinetics as expressed by the Johnson-Mehl-Avrami (JMA) model (Johnson, Mehl, 1939, p.416), 
(Avrami, 1939, p.1103), (Avrami, 1940, p. 212), (Avrami,1941, p.177), and probably due to a more complex transformation process such as a process described by the two parameter autocatalytic Šesták-Berggren reaction model. Accordingly, the JMA model is valid in the non-isothermal conditions provided that a new crystalline phase grows from a constant number of nuclei and all nucleation is completed before the macroscopic crystal growth started. This so-called site saturation is an important condition for the isokinetic crystallization process (Henderson, 1979, p.301). From the above facts, it seems that the nucleation and growth processes are probably overlapped for a fine $\mathrm{NiO}$ powder sample and therefore, the overall crystallization cannot be described by the JMA model. The autocatalytic Šesták-Berggren reaction model can be used for a quantitative description of the investigated complex reduction process of $\mathrm{NiO}$ under non-isothermal conditions which involved both nucleation and growth (Janković, et al, 2007, pp.48-55 ), (Sestak, Berggren, 1971, p.1). Such behaviour of the investigated system is confirmed from the complex dependence of the apparent activation energy $\left(E_{a}\right)$ on the degree of conversion ( $\alpha)$, and this dependence is a natural consequence of the existence of the distribution of apparent activation energies, which leads to the accidental distribution of the reaction times. In other words, the evaluated $d d f E_{a}$ 's represents the corresponding active sites reactivity distributions at different temperature-programmed rates. From the changes of the basic characteristics of $d d f E_{a}$ 's with the heating rate $\left(v_{h}\right)$, the complex nature of the investigated reduction process can be established.

\section{Conclusion}

The differential conversion curves of the non-isothermal $\mathrm{NiO}$ reduction process by hydrogen are fitted by the Weibull (non-isothermal) probability density function (Wpdf), in a wide range of the degree of conversion ( $\alpha=$ $0.06-0.96$ ). It was established that the considered process at 2.5, 5 and $10^{\circ} \mathrm{C} \mathrm{min}-1$ can be very well described by asymmetrical density distribution functions with shape parameters for $2 \leq \beta \leq 3$. On the other hand, the experimental differential conversion curve at $20{ }^{\circ} \mathrm{C} \mathrm{min}{ }^{-1}$ can be very well fitted with a highly symmetrical density distribution function for $\beta>3(\beta=$ 3.20) which corresponds to the normal distribution function. It was established that the Weibull distribution parameters $(\beta$ and $\eta)$ show different dependencies on the heating rate of the system $\left(v_{h}\right)$ (the shape parameter $(\beta)$ - linear form and the scale parameter $(\eta)$ - exponential form).

The model independent values of the apparent activation energy were calculated using the Friedman's isoconversional method. It was found that 
the calculated apparent activation energy depends on the degree of conversion, $\alpha$, and it shows a constant value in the range of the degree of conversion $0.20 \leq \alpha \leq 0.60\left(E_{a}=90.8 \mathrm{kJmol}^{-1}\right)$, for the temperature limited range of $250-400{ }^{\circ} \mathrm{C}$. An interesting fact from a practical point of view should be noted -for example, a sample of nickel oxide doped with nanosized palladium $(\mathrm{Pd})$ particles might reduce the value of the apparent activation energy. Namely, the well-known additional catalytic effect of $\mathrm{Pd}$ nano-particles can mainly promote the adsorption and diffusion processes (processes that occur even with a lower $E_{a}$ value than the above mentioned) of hydrogen on $\mathrm{NiO}$ surface, making possible the "inversion redox system" of type $\mathrm{Pd} / \mathrm{PdO}_{x}$. This can undoubtedly lead to spillover hydrogen $(\mathrm{SH})$ and is capable of entering into almost all reactions typical of hydrogen activated on the surface of a platinum group metal.

It was established that if $E_{a}$ and $A$ depend on $\alpha$, the kinetic parameters are correlated through the relation of the compensation effect. The true compensation effect relation evaluated from the Friedman's isoconversional method, for the investigated reduction process of $\mathrm{NiO}$, was established. By knowing the Weibull distribution function of reaction times, it is possible to determine the density distribution function of the apparent activation energies ( $\left.d d f E_{a}\right)$ at different heating rates. The obtained values of $E_{a, \max }$ calculated from ddf $E_{a}$ 's at all heating rates are in good agreement with the value of $E_{a}$ calculated using the Friedman's method in a conversion range of $0.20 \leq \alpha \leq 0.60$. It was established that the heating rate has a considerable influence on some important characteristics of the density distribution function of the apparent activation energy, especially on the shape factor (SF). It was conluded that only for $v_{h}=20$ ${ }^{0} \mathrm{C} \mathrm{min}^{-1}$, the density distibution function of the apparent activation energy exhibits the asymmetry factor which is greater than unity (SF $>1)$, while for the other values of the heating rates, the ddf $E_{a}$ 's exhibits the asymmetry factor lower than unity $(\mathrm{SF}<1)$. It was established that the changes of the symmetry of density distribution functions may be an indication for deviations from the simple crystallization kinetics as expressed by the Johnson-Mehl-Avrami (JMA) model, and this behaviour is probably due to a more complex transformation process such as a process described by the two-parameter autocatalytic Šesták-Berggren reaction model. Accordingly, for nano-sized $\mathrm{NiO}$ samples, the nucleation and growth processes are probably overlapped and in that case, the overall crystallization cannot be described by the JMA model. Based on the obtained results, the non-isothermal reduction process of $\mathrm{NiO}$ under hydrogen atmosphere follows the two-parameter autocatalytic ŠestákBerggren reaction model which gives a quantitative description of a com- 
plex process. It was also concluded that such behaviour leads to a complex dependence of the apparent activation energy $\left(E_{a}\right)$ on the degree of conversion $(\alpha)$.

It should be noted that the observed auto-catalytic effect in industrial applications is of great importance since it is used for the production of metals and for drastic reductions of their separation time as well as for the preparation and conduct of hydrotreating and hydrogenolysis catalysts.

\section{Literature}

Agrawal, R.K. 1986. On the compensation effect. Journal of Thermal Analysis, 31(1), p.73-86. doi:10.1007/BF01913888

Anthony, D.B., \& Howard, J.B. 1976. Coal devolatilization and hydrogastification. AlChE Journal, 22(4), p.625-656. doi:10.1002/aic.690220403

Avrami, M. 1939. . J. Chem. Phys., 7, p.1103.

Avrami, M. 1940. . J. Chem. Phys., 8, p.212.

Avrami, M. 1941. Granulation, phase change, and microstructure: Kinetics of phase change. III. Journal of Chemical Physics, 9(2), p.177. doi:10.1063/1.1750872

Bandrowski, J., Bickling, C.R., Yang, K.H., \& Hougen, O.A. 1962. . Chemical Engineering Science, 17, p.379.

Benton, A.F., \& Emmett, P.H. 1924. . Journal of the American Chemical Society, 46(12), p.2728. doi:10.1021/ja01677a018

Braun, R.L., \& Burnham, A.K. 1987. . Energy Fuels, 1, p.153.

Budrugeac, P., \& Segal, E. 1995. . ICTAC News, 28, p.33.

Burnham, A.K. 2005. . Chem. Eng. J, 108, sp.47.

Burnham, A.K., \& Braun, R.L. 1999. . Energy Fuels, 13, p.1. p.19432.

Burnham, A.K., Weese, R.K., \& Weeks, B.L. 2004. . J. Phys. Chem. B, 108,

Campbell, J.H., Gallegos, G., \& Gregg, M.L. 1980. . Fuel, 59, p.727.

Cantú, R.G.A., Mcewen, J.S., \& Gaspard, P. 2011. . Phys. Rev. E, 83, p.1.

Chen, D., Gao, X., \& Dollimore, D. 1993. . Thermochim. Acta, 215, p.109. $\mathrm{VCH}$.

Delmon, B. 1997. Handbook of Heterogeneous Catalysis. New York: Wileych. 11.

Delmon, B. 1969. Introduction á la cinétique hétérogéne. Paris: Technip.

Freund, H. 1999. . Faraday Discussions, 144, pp.1-31. doi:10.1039/a907182b

Friedman, H.L. 1963. . J. Polym. Sci. Part C, 6, p.183.

Furstenau, R.P., Mcdougall, G., \& Langel, M.A. 1985. . Surf. Sci., 150, p.55.

Galwey, A.K. 1977. . Adv. Catal, 26, p.247.

Henderson, D.W. 1979. . J. Non-Cryst. Solids, 30, p..301.

Henrich, V., \& Cox, P. 1994. Surface science of metal oxides. Cambridge: Cambridge University Press. 
Janković, B., Adnađević, B., \& Mentus, S. 2008. . Chem. Eng. Sci., 63, p.567.

Janković, B., Adnadević, B., \& Mentus, S. 2007. The kinetic analysis of non-isothermal nickel oxide reduction in hydrogen atmosphere using the invariant kinetic parameters method. Thermochim. Acta , 456(1), p.48-55. doi:10.1016/j.tca.2007.01.033

Johnson, W.A., \& Mehl, R.F. 1939. . Trans. Amer. Inst. Min. Metal. Petro. Eng, 135, p.416.

Kissinger, H.E. 1956. . J Res. Nat. Bur. Standards, 57, p.217.

Kissinger, H.E. 1957. Reaction kinetics in differential thermal analysis. Anal. Chem. , 29, p.1702-6. doi:10.1021/ac60131a045

Klarić, I., Roje, U., \& Kovačić, T. 1995. Kinetics of isothermal thermogravimetrical degradation of PVC/ABS blends. Journal of Thermal Analysis, 45(6), p.1373-1380. doi:10.1007/BF02547431

Koga, N. 1994. . Thermochim. Acta, 244, p.1.

Koga, Y., \& Harrison, L.G. 1984. Comprehensive Chemical Kinetics. Amsterdam: Elsevier.

Kolar-Anić, Lj., Veljković, S., Kapor, S., \& Dubljević, B. 1975. . J. Chem. Phys., 63, p.663.

Kolar-Anić, Lj., \& Veljković, S. 1975. . J. Chem. Phys., 63, p.669.

Kung, H.H. 1989. Transition Metal Oxides: The surface Chemistry and Catalysis. New York: Elsevier.

Lakshmanan, C.C., Bennett, M.L., \& White, N. 1991. . Energy Fuels, 5, p.110.

Lakshmanan, C.C., \& White, N. 1994. . Energy Fuels, 8, p.1158.

Langel, M.A. 1985. . Surf. Sci., 164, p.543.

Lescop, J.P., Jay, B., \& Fanjoux, G. 2004. . Surf. Sci., 548, p.83.

Lin, C.K., \& Berndt, C.C. 1995. Statistical analysis of microhardness variations in thermal spray coatings. Journal of Materials Science, 30(1), pp.111-117. doi:10.1007/BF00352139

Mcguinness, M.J., Donskoi, E., \& McElwain, D.L.S. 1999. . Appl. Math. Lett., 12, p.27.

Mentuš, S., Majstorović, D.M., Tomić, B.S., \& Dimitrijević, R.Z. 2005. Reduction of NiO-WO3 oxide mixtures synthesized by gel-combustion technique: A route to Ni-W alloys. Mater. Sci. Forum , 494, pp.345-350. doi:10.4028/0-87849-971-7.345

Miura, K., \& Maki, T. 1998. . Energy Fuels, 12, p.864.

Moriyama, J., \& Yamaguchi, A. 1964. . Nippon Kinzoku Gakkaishi, 28, p.831.

Plait, A. 1962. . Ind. Qual. Contro, 19, p.17.

Richardson, J.T., Lei, M., Turk, B., Forster, K., \& Twigg, M.V. 1994. . Appl. Catal. A, 110, p.217.

Richardson, J.T., Scates, R., \& Twigg, M.V. 2003. X-ray diffraction study of nickel oxide reduction by hydrogen. Applied Catalysis A: General, 246(1), pp.137-150. doi:10.1016/S0926-860X(02)00669-5

Rodriguez, J.A., Hanson, J.C., Frenkel, A.I., Kim, J.Y., \& Pérez, M. 2002. Experimental and theoretical studies on the reaction of $\mathrm{H}(2)$ with NiO: Role of $\mathrm{O}$ 
vacancies and mechanism for oxide reduction. J Am Chem Soc, 124(2), pp.34654. pmid:11782187. doi:10.1021/ja0121080

Sestak, J., \& Berggren, G. 1971. Kinetics of the mechanism of solid-state reactions at increasing temperatures. Thermochim. Acta, 3, p.1. doi:10.1016/0040-6031(71)85051-7

Shih, S.M., \& Sohn, H.Y. 1980. .Ind. Eng. Chem. Process Des. Dev., 19, p.420.

Staszczuk, P., Sternik, D., \& Kutarov, V.V. 2002. . Journal of Thermal Analysis and Calorimetry, 69(1), pp.23-36. doi:10.1023/A:1019973303894

Stern, A.C., Boubel, R.W., Turner, D.B., \& Fox, D.L. 1984. Fundamentals of Air Pollution, 2nd ed.Orlando, FL: Academic Press.

Utigard, T.A., Wu, M., Plascencia, G., \& Marin, T. 2005. . Chem. Eng. Sci., 60, p.2061.

Vyazovkin, S.V., Goryachko, V., \& Lesnikovich, A.I. 1992. . Thermochim. Acta, 197, p.41.

Vyazovkin, S., \& Linert, W. 1995. . Int. Rev. Phys. Chem., 14, p.355.

Vyazovkin, S., \& Linert, W. 1995. . Chem. Phys., 193, p.109.

Vyazovkin, S., \& Wight, C.A. 1999. . Thermochim. Acta, 340-341, p.53.

Vyazovkin, S., \& Wight, C.A. 1997. Kinetics in solids. Annual review of physical chemistry, 48,

doi:10.1146/annurev.physchem.48.1.125

pp.125-49.

pmid:15012442.

Weibull, W. 1951. A statistical distribution function of wide applicability. ASME Journal of Applied Mechanics, 18, pp.293-297.

Wu, Y., He, Y., Wu, T., Chen, T., Weng, W., \& Wan, H. 2007. . Mater. Lett., 61, p.3174.

Yagi, S., \& Kunii, D. 1955. . U: Proceedings of the 5th International Symposium on Combustion. New York: Reinhold.

PROCENA FUNKCIJE RASPODELE PRIVIDNE ENERGIJE AKTIVACIJE ZA NEIZOTERMNU REDUKCIJU NANOPRAHOVA OKSIDA NIKLA

OBLAST: materijali, hemijske tehnologije

VRSTA ČLANKA: pregledni članak

Sažetak:

Diferencijalne konverzione krive neizotermnog redukcionog procesa NiO sa vodonikom nadomeštene su Vejbulovom (neizotermnom) funkcijom gustine verovatnoće (Wpdf), u širokom opsegu stepena konverzije $(\alpha=0,06-0,96)$. Utvrđeno je da Vejbulovi parametri raspodele $\left(\beta\right.$ i n) pokazuju različite zavisnosti od brzine zagrevanja sistema $\left(v_{h}\right)$ (parametar oblika $(\beta)$ - linearni oblik i parametar skale $(\eta)$ - eksponencijalni oblik). Modelno nezavisne vrednosti prividne energije aktivacije izračunate su korišćenjem Fridmanove izokonverzione metode. Utvr- 
đeno je da izračunata prividna energija aktivacije zavisi od stepena konverzije, $\alpha$, i pri tome pokazuje konstantnu vrednost u opsegu stepena konverzije 0,20 $\leq \alpha \leq 0,60\left(E_{a}=90,8 \mathrm{~kJ} \mathrm{~mol}^{-1}\right)$. Znajući Vejbulovu funkciju raspodele reakcionih vremena, moguće je odrediti funkciju gustine raspodele prividne energije aktivacije na različitim brzinama zagrevanja. Utvrđeno je da su promene u simetriji funkcija gustine raspodela indikacija za odstupanja od jednostavne kinetike kristalizacije, kao što je izraženo putem Johnson-Mehl-Avrami (JMA) modela, što verovatno pripada mnogo složenijem procesu transformacije, kao što je proces opisan dvoparametarskim autokatalitičkim ŠestákBerggrenovim modelom.

Ključne reči: nikl-oksid, neizotermna redukcija, prividna energija aktivacije, funkcija gustine raspodele, stvarni kompenzacioni efekat.

Datum prijema članka/Paper received on: 04. 10. 2013.

Datum dostavljanja ispravki rukopisa/Manuscript corrections submitted on: 05. 11. 2013.

Datum konačnog prihvatanja članka za objavljivanje/ Paper accepted for publishing on:

07. 11. 2013. 